International Journal of Applied Linguistics \& English Literature

ISSN 2200-3592 (Print), ISSN 2200-3452 (Online)

Vol. 1 No. 2; July 2012

\title{
A Sociolinguistic Analysis of Metathesis in Azeri Language
}

\author{
Biook Behnam (Ph. D.) \\ Department of English Language, Islamic Azad University, Tabriz Branch, Iran \\ E-mail: behnam_biook@yahoo.com \\ Behzad Rassekh-Alqol (Corresponding author) \\ Department of English Language, Islamic Azad University, Tabriz Branch, Iran \\ Tel: +98-914-867-9761Ｅ-mail: behzad_rassekh@yahoo.com
}

Received: 09-05- 2012

Accepted: 12-06- 2012

Published: 01-07- 2012

doi:10.7575/ijalel.v.1n.2p.56

URL: http://dx.doi.org/10.7575/ijalel.v.1n.2p.56

\begin{abstract}
This study tries to investigate the correlation between sociolinguistic parameters such as sex, age, and social class and the use of metathesis in Azeri. There have been few studies from a sociolinguistic perspective on the use of metathesis. Through studying the stigmatized forms of speech in Azeri, the present study indicates that a significant relationship exists between extralinguistic variables and metathesis as a phonological process. The subjects of the study were Azeri speakers living in different districts of Tabriz categorized by three socioeconomically different groups. The statistical analyses of data indicate that there is an intimate and reciprocal relationship between linguistic behavior and social structure.
\end{abstract}

Keywords: sociolinguistics, phonological processes, metathesis, Azeri

\section{Introduction}

The sociolinguistic literature is rich in the studies that seek to relate linguistic data to social characteristics of language users (Chaika, 1990; Guy, 1988; Holms, 1992; Hudson, 1990; Keshavarz, 2000; Labov, 1972; Llamas, Mullany and Stockwell, 2007; Trudgill, 1983a; Wardhaugh, 1993). Social and communicative factors also play an important role in shaping language sound structure, as work in the field of sociolinguistics has made abundantly clear (Labov 1980). From a social perspective, the need to conform to a linguistic norm, for example, can exert influence over an individual's cognitive language sound patterns. The need in a communicative system to use forms that others will identify and accept also influences sound systems. Thus, the extent to which a particular sound process spreads throughout a language, or is maintained at all, is influenced by communicative factors.

Data collection and fieldwork play an important role in the study of sociolinguistic variation since its advocates argue both that it is the only way to accurately gain a picture of a person's language use (Labov 1996) on the inadequacy of intuition as a source of information on language structure and that the most systematic grammar of a dialect resides in the vernacular language of the speech community (Labov 1972). Great care is taken, therefore, to establish corpora of ethical recordings collected in relaxed circumstances from a wide range of speakers in the community. Students of sociolinguistic variation can gain valuable insight into the subject by conducting their own research: through rapid anonymous surveys (short surveys investigating one linguistic feature from many people in a short space of time) (Labov 1972) and subsequently through tape-recorded data collection and analysis in a relevant community. (Milroy, 1987; Milroy and Gordon, 2003) provide useful introductions to fieldwork methodology for sociolinguistic variation.

Labov's intention when establishing sociolinguistic variation as an approach to investigating language was not simply to make what in many cases appear to be obvious correlations between social factors and language use, but to demonstrate how language changes spread through society. He showed (Chambers, 2003; Chambers and Trudgill, 1998; Labov, 1972), by carefully plotting a speaker's social position alongside their use of linguistic variables, that linguistic changes tended to be led by certain social groups - not by the lowest or highest social classes in society as we might expect, but by the central groups - the upper working and lower middle classes. Labov found that upper working class speakers tended to be the leaders of unconscious linguistic changes that Page $\mid 56$ 
International Journal of Applied Linguistics \& English Literature

ISSN 2200-3592 (Print), ISSN 2200-3452 (Online)

Vol. 1 No. 2; July 2012

were more common in casual speech, and that the lower middle class led changes towards overtly prestigious standard forms.

Language changes, of course, take time, and one question that vexed linguists was how to observe changes in progress given that they take so long. It was previously assumed that change could only be observed retrospectively, after different states of the dialect had been observed at different points in time and comparisons made subsequent to several observations. Labov simulated a broad time span by adopting a so-called apparenttime method. He compared speakers of different ages (who had acquired language at different points in time) instead of comparing people of a particular age now with those of that same age 20, 40 etc years ago. Naturally, this method shortens the length of time required to conduct the research, but questions have been raised about this method since it assumes that people's dialect remains fairly stable from adolescence onwards (Chambers, 2003; Eckert 1997).

The model of analyzing language variation and change that Labov developed has been extremely popular and has been applied to many speech communities around the world. Recent approaches, however, whilst accepting the basic framework (e.g. the linguistic variable), have suggested that sociolinguistic variation studies have been sociologically naïve by correlating isolated social facts about a speaker (e.g. their gender, their social class, their ethnicity) with language use, rather than observing how social groups form and evolve and analyzing the dialect that emerges from that social practice. So rather than saying 'here are some broad social categories, let's look at the language use of each category' (a top-down approach) researchers are beginning to propose that we say 'let's examine self-forming social groups and see if these groupings are reflected in linguistic structure' (a bottom-up approach). One researcher who has taken this latter approach is (Eckert, 2001). She engaged in extensive ethnographic fieldwork in a secondary school in Detroit in order to gradually piece together a picture of who hung out with who, who were the central members and the less central members of the emergent groups and so on. She was then able to plot group membership against a large number of linguistic variables. Her research is particularly important in making us realize just how gross categories such as 'female' or 'adolescent' or 'working class' are, lumping together very different people into the same group, and that a sensitivity to how real groups of people are formed and maintained provides a very rich seam for future sociolinguistic analysis.

\subsection{The nature of metathesis}

Metathesis is the process in which sound segments reverse their order. In other words, we employ a practical definition of metathesis as local reversal of adjacent units, and as Hume (2001) claims metathesis is constrained to local movement. She believes that two key elements should be examined meticulously; data and theory. Although there are a large number of metathetic studies in the literature, little attention is paid to the accessibility of linguistic metathesis, such as the required circumstances in order to apply metathesis, the reasons for metathesis to occur, and the cases in which metathesis interacts within other significant sound structures. In order to develop an explanatory theory of sound systems, she emphasizes on a deep understanding of basic phonological processes.

Two types of metathesis are identified: diachronic and synchronic. Diachronic or historical metathesis refers to variation in a string of sounds over a period of time, such as early Persian liquid metathesis (Hock, 1985). Blevins \& Garrett (2004) distinguish four relocations which result in metathesized forms, and each of them is based on the characteristics of specific phonetic features: perceptual metathesis; compensatory metathesis; articulatory metathesis; and auditory metathesis.

In synchronic metathesis, a language meets the criteria if it demonstrates alterations as metathesized forms, such as metathesis as a transformation in Faroese (Chomsky and Halle, 1968).

According to the framework of Optimality Theory (Prince \& Smolensky 1993), metathetic changes can be regarded as process (a detached mechanism) or by-product (the segmental reordering is a surface result of other intermingling phonological processes). Metathesis is considered to be a process in Correspondence Theory (McCarthy \& Prince, 1995), and it can be easily accessible. However, Mielke \& Hume (2001) relate rarity of metathesis to the fact that metathesized forms hinder word recognition.

There appear to be instances of metathesis, which are indicating a phonetic process, especially a perceptual process by the listeners. In an attempt to incorporate phonetics into phonology, Hume (2001) proposes a view in which production and perception are integrated in the phonology; arguing that perceptual enhancement has a vital role in metatheses. Whereas the incorporation of phonetics into phonology is challenging, Blevins \& Garrett (2004) argue strongly that metathesis does not function to enhance emerging system. 
Van Oostendorp and colleagues (2011) identify local metathesis comprising the sequences CC, CV and VV. In CC metathesis, the processes are grouped in relation to the characteristics of the specific units including the distinct role of sibilants, place of articulation, and manner of articulation. In this paper, all examples are CC metatheses from Azeri language involving /b/, /r/, /p/,/s/, /x/, and/k/.

\subsection{The Language Situation in Azerbaijan}

Azerbaijan bilingual community is unique, just as every sociocultural situation in which language is used. For most individuals, the first language learned-the mother tongue- is also the most used and, conversely 'second language' tends to be secondary in terms of use. But in Azerbaijan, the mother tongue, i.e. Azeri, in spite of its long literary tradition of more than 800 years and presumably for political reasons, has lost its status as primary official medium of communication and education and is limited to oral communication, home and friendship and is replaced, in other domains, by Persian. However much may Azeri borrow from other languages; the result is never a truly mixed language, but simply a much modified form of Azeri (Torabi 2002). If Azeri speakers can now call upon the entire vocabulary of Persian or Russian or any other language, their language is still Azeri, for it uses Azeri grammatical patterns and the language is the product of an unbroken development from an earlier form of language.

Many instances of metathesis can be found in Azeri, such as /kirbit/ for /kibrit/ 'match', /diks/ for /disk/ 'disc', /torpak/ for /toprak/ 'soil', and /nuxsæ/ for /nusxæ/ 'prescription. However, apart from its phonological reality, metathesis is of sociolinguistic significance in Azeri since a strong social stigma is attached to its use in this language. In fact, metathesis in Azeri can be considered a good indicator of educational and social class background as it occurs only in the speech of the uneducated and members of the lower classes of the society. As a result, education in this study is considered as one of the main factors of social class membership.

Review of literature shows that metathesis, as a phonological process, has only been studied from a purely linguistic perspective. Therefore, this is the first attempt to investigate metathesis in Azeri from a sociolinguistic point of view as an evidence for the relationship between language and society.

This study is based on the assumption that the social characteristics of individuals in a speech community determine the linguistic behavior of those individuals. So the sex, age, and social class of the speakers affect their utterances. The present study seeks to answer the following questions:

1. Is the use of metathesis related to the sex factor?

2. Is the use of metathesis related to the age of speakers?

3. Is the use of metathesis related to social class?

\section{Method}

\subsection{Subjects}

The subjects of the present study were 120 Azeri speakers living in different districts of Tabriz. They were randomly selected from different strata of society. That is, stratified sampling, which is a common procedure in sociolinguistic research, was employed.

On the basis of the information elicited in the questionnaire, the subjects were categorized into:

(a) Two sex groups (Male vs. Female)

(b) Three age groups (18-29, 30-45, and 46-over)

(c) Three social class groups (Upper Middle Class, Lower Middle Class, and Working Class).

The main criteria for establishing social class membership were based on the subjects' education, occupation, and socioeconomic status. That is, the informants were asked primarily about their own education and occupation as well as the education and occupation of their parents and their spouses, if they were married. They were also asked questions about their monthly income. Since some were reluctant to provide information about their income, some indirect questions were included in the questionnaire to arrive at a reliable estimate of their economic status. These indicators included questions about their housing whether they owned a private property or they were tenants, the kind of carpets (hand-woven or machine-woven) they used in their houses, and the amount of money they spent on their children's education. Thus an individual's social class was established by his combined rank on these scales. 
Vol. 1 No. 2; July 2012

\subsection{Measuring Instruments}

Two measuring instruments were used in this study. First, a questionnaire was designed whose purpose was to elicit information about the socioeconomic status of the informants as well as their age and sex. Second, the informants were given pictures of objects and were asked to name them and their pronunciations were ranked (standard or metathized) on the spot in the questionnaire. They were also provided with scenarios and asked to react verbally. For instance, they were asked what they would take on a picnic to keep tea hot. The expected response here was /filask/ 'flask'; however, this word is likely to undergo the phonological process of metathesis in the speech of some Azeri speakers and change to /filaks/.

\subsection{Procedure}

The goals of the research were explained to the informants and they were assured that the personal information they revealed in the questionnaire would not be revealed. In order to ascertain this point, the subjects were not asked to write their names in the questionnaire. Therefore, they felt convenient in responding the questions.

After the data were collected, the subjects were categorized into different social class and age groups on the basis of the information provided in the questionnaires. Then the frequency of occurrence of metathesized words and expressions was calculated. The interaction of extralinguistic variables with the linguistic variable 'metathesis' will be illustrated by means of histograms.

\section{Results and Interpretations}

As stated earlier, since no research has, to date, been carried out on the relationship between nonlinguistic parameters and the use of metathesis, an experiment was conducted to investigate whether extralinguistic factors such as age, sex, and social class had any impact on the use of metathesis in Azeri.

The corpus of the data upon which the analysis rests consists of more than 2000 occurrences of words and expressions with the likelihood of metathesis in the speech of Azeri speakers. The subjects' pronunciation of the words and expressions they produced was ranked on the spot. Then, variation in the use of metathesis was carefully examined and the following results were obtained. In order to show how each group of subjects performed on the verbal tasks, the mean scores of each group were given to graphic displays as presented in the relevant figures.

With regard to the first research question concerning the relationship between the sex of the subjects and the use of metathesis, in all cases the frequency of occurrence of metathesis was higher in the speech of males than that of females: the total percentage of the occurrence of metathesis by male subjects was 52.08 compared to 49.28 by females. This is graphically shown in Figure1.

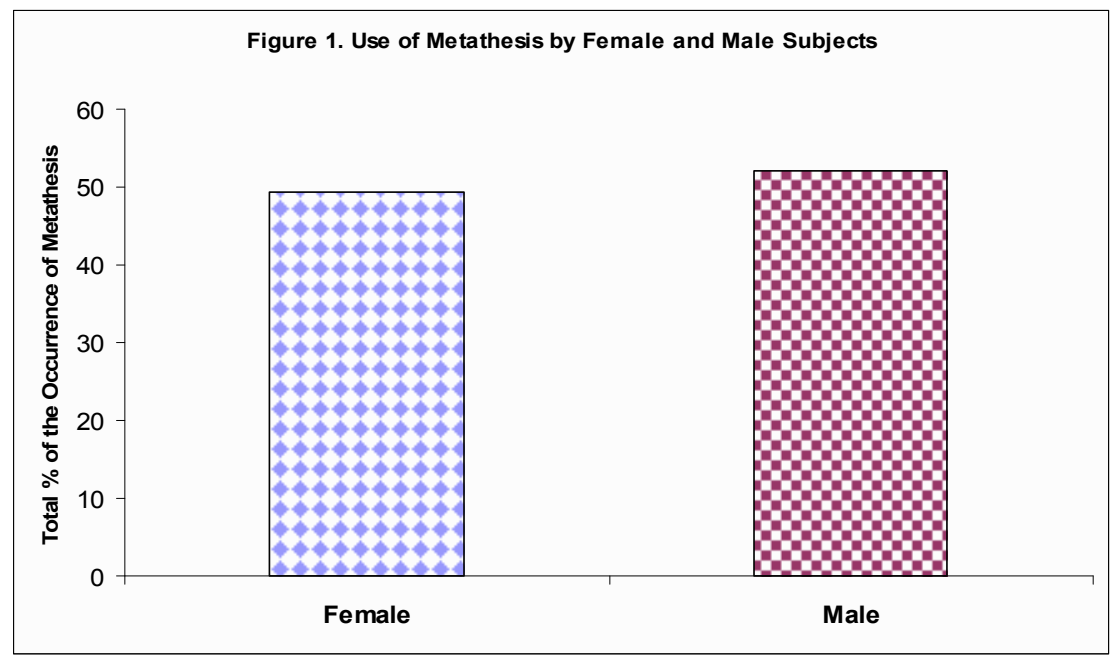

These results are in line with the general conclusion drawn from other sociolinguistic studies (Chambers, 2003; Chambers and Trudgill, 1998; Cheshire, 1982; Coates, 1986; Coates and Cameron, 1988; Graddol and Swann, 1989; Holmes, 1985, 1988, 1990; Keshavarz, 2000; Mulac, et al 1986; Trudgill, 1983b) that women are more sensitive to the prestigious variety and tend to avoid stigmatized forms more than men of the same social class do. 


\section{International Journal of Applied Linguistics \& English Literature}

ISSN 2200-3592 (Print), ISSN 2200-3452 (Online)

Vol. 1 No. 2; July 2012

Furthermore, it has been recognized that quantitative differences can be very salient indeed to speakers themselves - so much so that even a difference of a few percent in usage can lead to the association of a particular linguistic form with a particular social group. In New Zealand English the use of High Rising Tones is very strongly associated with young women, yet they only use the HRT 3\% percent more often than young men. Clearly small quantitative differences can signal quite important social information about a linguistic variable. (Britain1998).

With regard to the second research question concerning the relationship between the age of the subjects and the use of metathesis, a significant relationship was found between age and the frequency of occurrence of metathesis. The total percentages of metathesis for the fist age group (18-29) was 52.5, for the second group (3045) 46.96, and for the third group (46-over) 50.44.These findings are in line with other age-related sociolinguistic studies (Baily, 1973; Chambers and Trudgill, 1998; Downes,1984; Eckert,1997; Labov,1966, 1972; Romaine, 1984; Trudgill, 1988)

Speaker age is considered the primary correlate of language change (Chambers 2002), and as such is generally included as independent variable in studies of language change. However, in contrast with other social variables (e.g., sex, socio-economic class), in sociolinguistics, age has not typically been of interest in and of itself: "there has been little, if any, research that has had age differences in language use as its primary focus" (Cheshire 1987). There is a dearth of research investigating" how word use changes across the life span" (Pennebaker and Stone, 2003). Indeed, most prior mainstream sociolinguistic research has focused on morphophonological variation, while syntactic, lexical, and pragmatic variation has remained under-investigated (Cheshire 2005). In sum, we know relatively little about how speakers from different age groups might differ in their linguistic choices, particularly at the lexicogrammatical level. Syntactic, lexical and pragmatic variation however cannot be tackled the same way as phonological variation, where a linguistic variable is identified by circumscribing relevant variants. Rather, we need approaches taking into account the fact that the social embedding of these forms may involve forms drawn from other linguistic levels beside themselves (Cheshire 2005). The relationship between age and the use of metathesis is graphically represented in Figure 2.

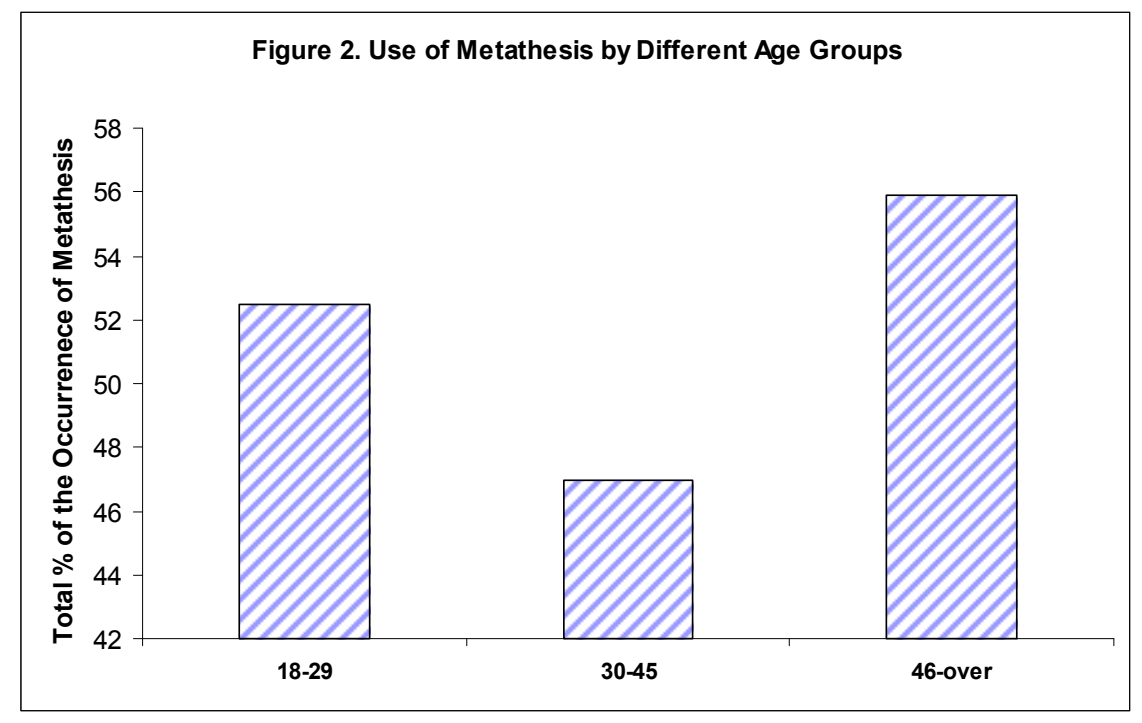

As it is noticed the second group (30-45) indicates the fewest frequency of occurrence of metathesis. Summarizing social dialect research with regard to age, Holmes (1992) concludes that "as people get older their speech simply becomes less dialectical and more standard"(p. 184). She further adds that "...there is general agreement that in their 'middle years' people are most likely to recognize the society's speech norms and use the fewest vernacular forms. ...they are most likely to use more standard forms". (p. 186). She emphasizes that young and older people reflect language change dramatically.

However in research conducted by Keshavarz (2000), the first age group had the fewest frequency of occurrence of the use of metathesis. He concluded that although non-linguistic parameters affect linguistic behavior of individuals in different societies, the nature and extent of their effect may vary from society to society. 


\section{International Journal of Applied Linguistics \& English Literature}

ISSN 2200-3592 (Print), ISSN 2200-3452 (Online)

Vol. 1 No. 2; July 2012

With reference to the third research question, the results indicate that a strong relationship exits between social class and the use of metathesis in Azeri. The total percentage of metathesis for Upper Middle Class (UMC) was 45.26, for Lower Middle Class (LMC) 50.32, and for Working Class (WC) 57.22. This is graphically illustrated in Figure 3.

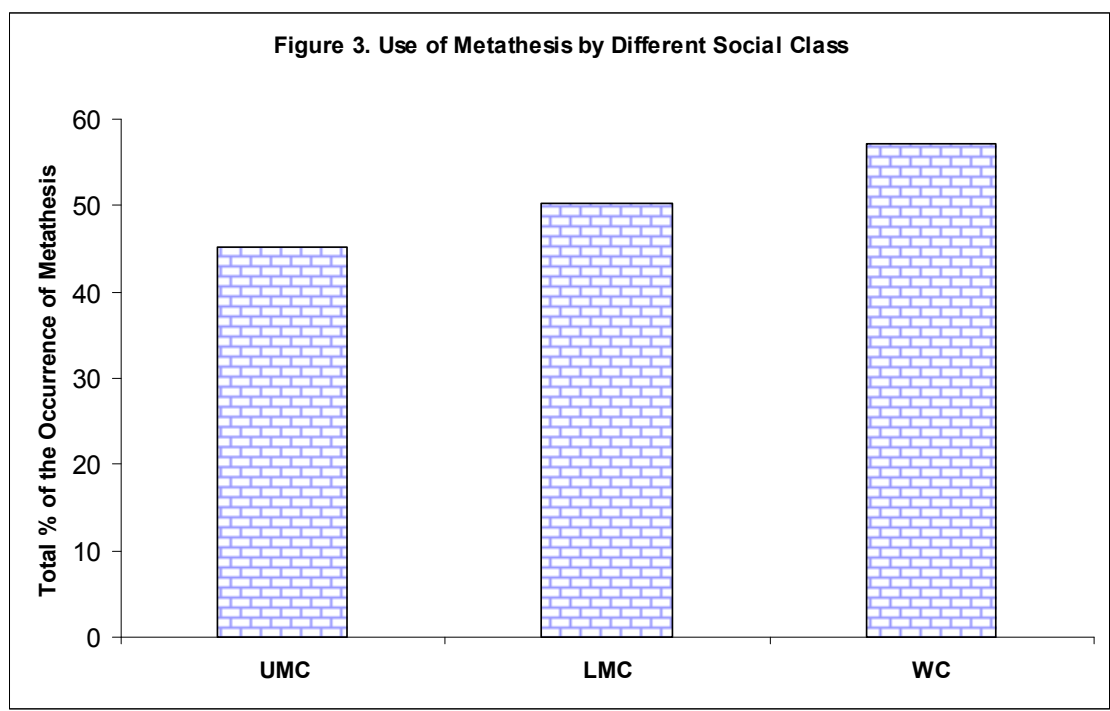

Thus, it can be concluded that members of the lower social class use more stigmatized linguistic forms than the upper classes. In other words, the higher individuals are on the social ladder, the less likely they are to use metathesis in Azeri. This is in line with the findings of other researchers in linguistics (Britain, 1998; Chambers, 2003; Chambers and Trudgill, 1998; Eckert, 2001; Keshavarz, 2000; Labov, 1966; Macaulay, 1977; Shuy, et al. 1968; Trudgill, 1974; Wolfram, 1969) which indicate that the lower the social, the more stigmatized forms are used. Another very frequently noted pattern is the tendency for women to use standard forms of stable dialect features more than men. One typical pattern found for dialect features that are stable (i.e. not undergoing change) is the correlation of the absence of third person present tense marking (e.g. 'she play', 'the boy sing') with social class membership in the city of Norwich in England (Trudgill 1974) - the 'higher' the social class of the speaker, the lower the absence of -s marking. As the final analysis of the data, the interaction of social class and sex with the linguistic variable metathesis was investigated. In all social classes the frequency of the use of metathesis by male subjects was higher than that by females. This is illustrated in Figure 4.

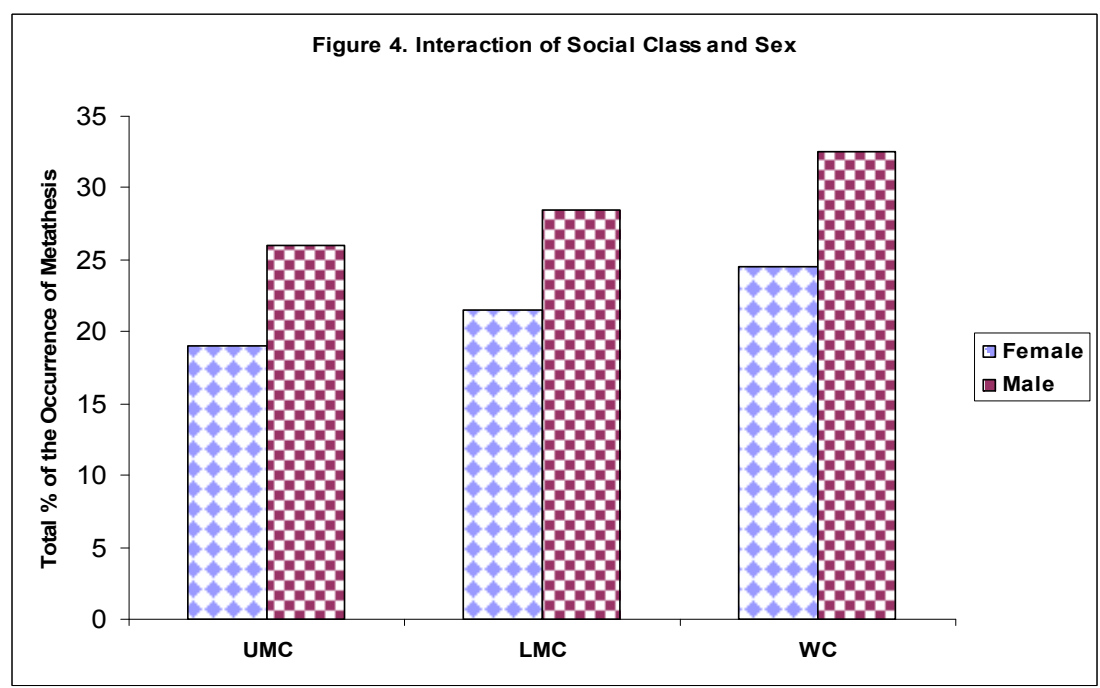

A very frequently noted pattern is the tendency for women to use standard forms of stable dialect features more than men. Trudgill's (1974) research in Norwich, confirms the results of the correlation of social class, speaker sex and the use of non-standard [n] variants of unstressed -ing suffixes. Within each social class group, women

Page $\mid 61$ 
International Journal of Applied Linguistics \& English Literature

ISSN 2200-3592 (Print), ISSN 2200-3452 (Online)

Vol. 1 No. 2; July 2012

consistently use less of the non-standard pronunciation than men. It is the regularity of these (and other) patterns that lends weight to the argument that variability is 'structured' socially (Chambers, 2003; Chambers and Trudgill, 1998).

\section{Conclusion}

As a conclusion, the findings of this study confirm the claim that a close relationship exits between language and society. That is, through studying the linguistic behavior of individuals in a speech community one can obtain a great deal of information about the social characteristics of those individuals. In other words, social structure is reflected in language structure and language use (Keshavarz 2000). More specifically, the findings of present research indicate that a significant relationship exists between extralinguistic variables and the use of metathesis as a phonological process. With regard to sex, the present investigation confirms the findings of previous studies that women used more "correct" and prestigious forms of language than did men. The findings are also in line with the general conclusion drawn from other sociolinguistic researches that younger people make more frequency use of vernacular and stigmatized forms. With reference to social class, the present study confirms other studies that the lower the social class, the more stigmatized forms are used.

\section{References}

Bailey, C. J. N. (1973). Variation and Linguistic Theory. Washington, DC: Center for Applied Linguistics.

Blevins, J. and A. Garrett (2004). The evolution of metathesis. In B. Hayes, R. Kirchner and D. Steriade (eds.) Phonetically based phonology. Cambridge: CUP.

Britain, D. (1998). Linguistic change in intonation: the use of High Rising Terminals in New Zealand English. In P. Trudgill \& J. Cheshire (eds.), The Sociolinguistics Reader: Volume 1: Multilingualism and Variation. London: Arnold.

Chaika, E. (1990). Language: The Social Mirror. Rowley Mass: Newsbury House Publishers.

Chambers, J. K. (2002). Patterns of variation including change. In The Handbook of Language Variation and Change (ed.) J. K. Chambers, P. Trudgill and N. Schilling-Estes, 349-372. Malden, MA: Blackwell.

Chambers, J. K. (2003). Sociolinguistic Theory. Oxford: Blackwell.

Chambers, J. K. \& P. Trudgill. (1998). Dialectology. Cambridge: Cambridge University Press.

Cheshire, J. (1982). Linguistic Variation and Social Function. In S. Romaine (ed.). Sociolinguistic Variation in Speech Communities. London: Edward Arnold.

Cheshire, J. (1987). Age and generation-specific use of language. In Sociolinguistics: An international handbook of the science of language and society, (ed.) U.Ammond, N. Dit tmar and K. Mattheier, 760-767. Berlin: Walter de Gruyter.

Cheshire, J. (2005). Syntactic variation and beyond: Gender and social class variation in the use of discourse-new markers. Journal of Sociolinguistics, 9 (4), 479-508.

Chomsky, N. \& Halle, M. (1968). The sound pattern of English. New York: Harper \& Row.

Coates, J. (1986). Women, Men and Language. London: Longman.

Coates, J. \& Cameron, D. (1988). Women in Their Speech Communities. London: Longman.

Crystal, D. (1997). A Dictionary of Linguistics and Phonetics. Oxford: Blackwell.

Downes, W. (1984). Language and Society. London: Fontana Paperback.

Eckert, P. (1997). Age as a sociolinguistic variable. In F. Coulmas (ed). The Handbook of Sociolinguistics. Oxford: Blackwell.

Eckert, P. (2001). Linguistic variation as social practice. Oxford: Blackwell.

Graddol, D. \& J. Swann. (1989). Gender Voices. Oxford: Blackwell.

Guy, G. (1988). Language and Social Class. In F. J. Newmeyer (ed.) Linguistics: The Cambridge Survey, IV, Language: The Socio-cultural Context. Cambridge: Cambridge University Press.

Holmes, J. (1985). Sex Differences and Miscommunication: Some Data from New Zealand. In J. B. Pride (ed.) Cross-cultural Encounters: Communication and Miscommunication. Melbourne: River Seine.

Page | 62 
International Journal of Applied Linguistics \& English Literature

ISSN 2200-3592 (Print), ISSN 2200-3452 (Online)

Vol. 1 No. 2; July 2012

Holmes, J. (1988). Paying Compliments: A Sex Preferential Positive Politeness Strategy. Journal of Pragmatics, $12(3), 445-65$.

Holmes, J. (1990). Hedges and Boosters in Women's and Men's Speech. Language and Communication, 10 (3)185-205.

Holms, J. (1992). An Introduction to Sociolinguistics. London: Longman.

Hudson, R. A. (1990). Sociolinguistics. Cambridge: Cambridge University Press.

Hume, E. (1998a). Metathesis in phonological theory: The case of Leti. Lingua, 104, 147-186.

Hume, E. (1998b). The Role of Perceptibility in Consonant/Consonant Metathesis. Proceedings of West Coast Conference on Formal Linguistics 17. 1998.

Hume, E. (2000). The Role of Speech Perception in PhMakashay, Matt (2001) Lexical effects in the perception of obstruent ordering. In E. Hume, Norval Smith and Jeroen van de Weijer.onology: The Case of Metathesis. Paper presented to the Department of Linguistics, University of Chicago.

Hume, E, N. S. \& Van de Weijer., J. (2001). Surface Syllable Structure and Segment Sequencing. HIL Occasional Papers. Leiden, NL: HIL.

Hume, E. (2001). A Model of the Interplay of Speech Perception and Phonology. In E. Hume \& K. Johnson (eds.), The Role of Speech Perception in Phonology. New York: Academic Press.

Keshavarz, M.H. (2000). Issues in Applied Linguistics: A sociolinguistic Analysis of Metathesis in Persian. Tehran: Rahnama Publishing Inc.

Labov, W. (1966). The Social Stratification of English in New York City. Washington, DC: Center for Applied Linguistics.

Labov, W. (1972). Sociolinguistic Patterns. Oxford: Blackwell.

Labov, W. (1980) Locating Language in Time and Space. New York: Academic Press.

Labov, W. (1996). When intuitions fail. Chicago Linguistic Society: Papers from the Parasession on Theory and Data in Linguistics, 32,76-106.

Llamas, C., L. M, \& Stockwell, P. (2007). The Routledge Companion to Sociolinguistics. Routledge.

Macaulay, R. K. S. (1977). Language, Social Class, and Education: A Glasgow Study. Edinburgh: Edinburgh University Press.

McCarthy, J. (2000). The Prosody of Phase in Rotuman. Natural Language and LinguisticTheory, 18 (1), 147-197.

McCarthy, J. and A. Prince (1995). Faithfulness and Reduplicative Identity. UMOP 18. 249-- - 384.

Mielke, J. and E. Hume (2001). Consequences of Word Recognition for Metathesis. In E. Hume, N. Smith and J. van de Weijer (eds) Surface Syllable Structure and Segment Sequencing. Leiden: HIL.

Milroy, L. (1987). Observing and Analyzing Natural Speech. Oxford: Blackwell.

Milroy, L., \& Gordon, M. (2003). Sociolinguistics: Method and Interpretation. Oxford: Blackwell.

Montreuil, J. (1981). The Romansch 'Brat'. Papers in Romance, 3(1).

Mulac, E. (1986). Male/Female Language Differences in a Public Speaking Situation. Communication Monographs 53, 2,115-29.

Pennebaker, J. W., \& Stone, L. D. (2003). Words of Wisdom: Language Use over the Life Span. Journal Personality and Social Psychology, 85 (2), 291-301.

Powell, J. V. (1985). An Occurrence of Metathesis in Chimakuan. In V. Acson and R. Leed (eds.), For Gordon H. Fairbanks. Honolulu: University of Hawaii Press.

Prince, A. and P. Smolensky (1993). Optimality Theory: Constraint interaction in generative grammar. ROA-537.

Romaine, S. (1984). The Language of Children and Adolescents. Oxford: Blackwell.

Seo, M., \& Hume, E. (2001). A Comparative OT Account of Metathesis in Faroeseand Lithuanian. In E. Hume, Norval Smith and Jeroen van de Weijer. (Paper also presented at the Scandinavian Conference on Linguistics,

Page $\mid 63$ 
International Journal of Applied Linguistics \& English Literature

ISSN 2200-3592 (Print), ISSN 2200-3452 (Online)

Vol. 1 No. 2; July 2012

Lund, Sweden, May 2000).

Shuy, R. W. (1968). Field Techniques in an Urban Language Study. Washington, DC: Center for Applied Linguistics.

Spencer, A. (1996). Phonology. Oxford: Blackwell.

Torabi, Mohammad Ali. (2002). Azarbaijani and T.E.F.L (A Contrastive Linguistic Approach To T.E.F.L. To Azarbaijani Bilinguals). Tabriz University Press

Trudgill, P. (1974). The Social Differentiation of English in Norwich. Cambridge: Cambridge University Press

Trudgill, P. (1983a). Sociolinguistics: An Introduction to Language and Society. Harmondsworth, England: Penguin Books.

Trudgill, P. (1983b). Social Identity and Linguistic Sex Differentiation. On Dialect. Oxford: Blackwell.

Trudgill, P. (1988). Norwich Revisited: Recent Linguistic Changes in an English urban Dialect. English Worldwide, 9, 33-49.

Van Oostendorp, M., Ewen, C. J., Hume, E. \& Rice, K. (2011). The Blackwll Companion to Phonology. Oxford: Blackwell

Wardhaugh, R. (1993). An Introduction to Sociolinguistics (2nd ed.). Oxford: Basil Blackwell.

Weinreich, U., W. Labov \&. Herzog, M. (1968). Empirical foundations for a theory of language change. In W. Lehmann \& Y. Malkiel (eds.), Directions for historical linguistics. 97-195. Austin: University of Texas Press

Wolfram, W. (1969). A Sociolinguistic Description of Detroit Negro Speech. Washington, DC: Center for Applied Linguistics. 